Some of the new private institutions-such as the Times School of Marketing and the Kirloskar Institute of Advanced Management-hardly bother to obtain recognition from the University Grants Commission's All India Council for Technical Education. Being market oriented, these institutions have the capacity to absorb their trainees in their own enterprises. Thus they enjoy more autonomy and less accountability.

\section{Issues at Stake}

Notably, India's private primary and secondary schools have greater credibility than private higher education institutions. The prevailing ambiguity about the quality of education provided by the new private institutions creates skepticism. Most have thrived primarily because of the craze among Indians for "degrees" and "diplomas." Only a tiny number of private higher education institutions are quality conscious. They do not face mandatory evaluation by the National Assessment and Accreditation Board, nor does the system protect the interests of students under the Consumers Act.

Ambiguity prevails over the very nomenclature of "private higher education"-making it difficult to distinguish government-aided private institutions from the nonprofit public or for-profit private ones. Most of the new private institutions function under the guise of charitable trusts. Though these

\section{The private institutions have succeeded in convert-}

ing the traditional "temples of learning" into market-oriented "diploma mills."

institutions are not allowed to earn any profits, most of them succeed in making huge profits by charging substantial fees and making underhand dealings at the time of admission. They are able to take advantage of anxious students, and their families who are not absorbed by the public universities.

The private institutions have succeeded in converting the traditional "temples of learning" into market-oriented "diploma mills." They know how to take advantage of the surge in demand for higher education and professional training in a country with a growing middle class of 350 million and 60 percent of the population below the age of 25 . The neoliberals and round-the-clock media have succeeded in spreading the myth that the more you study the better your job prospects. Private higher education in India has thus become a lucrative business.

The government and the judiciary are now bent on curbing the commodification and commercialization of higher education by the new private institutions in the name of equity and social justice. In a caste-ridden and hierarchical society, higher education remains the sole hope for the vast majorities toward social mobility. That is why the current coalition government is insisting upon reservation of up to 49.5 percent for the scheduled castes, scheduled tribes, and other backward classes through the 93rd constitutional amendment act. We also find frequent judicial interventions over trivial administrative matters pertaining to the common entrance exam, fee structure, and management quota.

In fact, two bills dealing with the contentious issues of reservation and regulation of private higher education are currently under active consideration in Parliament. Though passage of the earlier bill introduced in the Rajya Sabha (upper house) in August I995 was blocked by resistance from the private sector itself, some states-such as Uttar Pradesh, Uttaranchal, and Chattisgarh-succeeded in passing the private universities acts in the last several years. These developments have resulted in conflicts between the central and state governments and feuds between the judiciary and the executive.

\section{Planning for Higher Education Change in Madagascar}

\section{Fred M. Hayward and Hanitra Rasoanampoizina}

Fred M. Hayward is an independent higher education consultant who has worked in Africa, Asia, and the United States. Hanitra Rasoanampoizina is a research assistant and quality assurance specialist at the Ministry of National Education and Scientific Research in Madagascar. E-mails: hayward.fred.@att.net; rasoanampoizina@yahoo.com. Addresses: 3628 Van Ness St. NW, Washington DC, USA; lot IVC 104, Ambatomitsangana, Ankadifotsy, Antananarivo 101, Madagascar.

Tor the last year, work has been under way on a strategy for $\boldsymbol{F}$ higher education reform, quality improvement, and a transformation in Madagascar. After some delay, that process has been joined by the major tertiary institutions.

Higher education in Madagascar developed in the I950s as part of the French Institut des Hautes Etudes. The University of Antananarivo was established on this base in 1961 with 723 students focusing on law, medicine, pharmacy, science, and the arts. Five regional centers were established in I975, becoming regional universities in 1988 . In $1989 / 90$ the universities were required to admit all students who passed the baccalaureate. From I975 to I990 the number of students more than quadrupled, to 37,000 . Judging that experiment a costly failure, the government returned to competitive admissions, reducing the total number of students to an average of 20,000 from I994 through 2002. Increases since that time have been modest. In 2006 the total student population at the six public universities was 37,152.

Private tertiary institutions developed primarily during the past decade. Most provide training in business, languages, 
management, and computer science. In 2005 , the 50 recognized private higher institutions had 6,778 students (I9.50 percent of the total). The total number of students in tertiary education is 3 percent of the college-age group, compared to 8 percent for Africa as a whole.

\section{Challenges}

Among the most difficult challenges is to stem the tremendous loss of students from secondary school to graduation. Only half the 25,000 students who passed the baccalaureate at the end of secondary school were admitted to a university. Thirty-five percent of students fail in the first year, and I8 percent repeat-with devastating consequences for students and a waste of resources. Of those admitted, 42 percent will earn a diploma. Part of the problem is inadequate preparation in secondary school, as well as the fact that many go to universities because it is expected and because students receive little counseling about other opportunities.

Much of the university curriculum is out of date. Only 64 percent (2006) of the faculty have PhDs or their equivalent. Few do any research or publish. A recent study shows only 87 publications in major refereed journals in 2004 and I2I in 2005. Research experience is limited, which undermines the ability of faculty to train and to stimulate students. Teaching and learning are not highly valued or rewarded. There is a public perception that about half the university graduates are unemployed, although there have been no studies to verify this.

University faculty are aging. The system suffers from a hiring freeze of more than a decade. As a result, the average age of faculty members is 56 years, with only 15 faculty members

Only half the 25,000 students who passed the baccalaureate at the end of secondary school were admitted to a university. Thirty-five percent of students fail in the first year.

in all six universities under the age of 40 .

Gender equity among students is less of a problem in Madagascar than in many other developing countries, with 46 percent of students being women. On the other hand, only 29 percent of the teaching faculty are women at public institutions and only i 8 percent in private tertiary institutions.

Finance is a critical problem for universities. Government commits I8.2 percent of its budget to education and only 9.4 percent of that to higher education - the equivalent of $\$ 390$ per student. Government policy of scholarships for most students $(82$ percent in 2006$)$ without a means test has become an automatic budget liability, and 25 percent of recipients are from wealthy families. Students pay fees, but their contribution is limited. Attempts to increase fees or reduce scholar- ships would pose serious political risks. Added to these problems is the growing demand for access.

The system suffers from inertia. Senior university administrators resisted suggestions for reform until 2006 when new elections of presidents brought in leaders who are aware that Madagascar is far behind most of the rest of Africa and committed to improving quality. The new administrators, too, face the challenge of mobilizing support for reform.

\section{Planning for Change}

A new minister of education, Haja Nirina Razafinjatovo, was appointed in 2004 and is committed to making major changes in higher education. He brought dynamism and a new spirit to the ministry and recognized that transformation would require broad mobilization. He made a major commitment to quality improvement that is now part of the Madagascar Action Plan (2006) with "international norms and standards" as the first priority for higher education.

The minister's initial efforts to encourage change through the university presidents were largely rebuffed. His second initiative, a broad task force, was also unsuccessful. In the meantime, the minister worked with his staff and with some donor support in three areas. These initiatives were largely successful, including the first major faculty recruitment in more than a decade, establishment of the foundation for accreditation, a digital library, and a plan for PhD training abroad for promising MA/MS students.

The minister established a task team of ministry staff to begin work on an overall strategy for the transformation of postsecondary education. In early 2006 he began work with the newly elected presidents on an outline for change; in August he appointed a groupe de réflection made up primarily of university presidents and a working group of vice-presidents, leaders in education, and senior ministry personnel.

By October, significant progress had resulted in an outline for higher education changes, including accreditation, faculty development, a credit system, articulation between universities, upgrading and expansion of distance education, centers of excellence for regional universities, prioritization of recruitment priorities, improved governance, and enhancement of university finances.

In addition, a great deal of thought was given to alternatives to university education-expansion of technical training, establishment of a US community colleges-type institution to provide job skills and entrepreneurial training.

\section{Prospects}

What has been impressive about the ministry leadership, the groupe de réflection, and the working group is their commitment to change, their thoughtful exploration of options, cooperative spirit, and recognition of the difficulties ahead. Indeed, if transformation is to occur, it will require widespread support of the faculties, students, staff, the public, and government. Universities will need to improve their own efficiency, but 
there are few areas in which substantial savings can occur. Government and funders, too, will need to make a major commitment of additional funding-one-time upgrades to laboratories; ICT (information, communications, and technology); building repair; long-term commitments to quality improvement, faculty recruitment, training, and retention; and enhanced teaching and research facilities. The universities and the ministry will need to make the case to the public for increased higher education funding. Nonetheless, the opportunity to transform higher education exists in Madagascar today in ways it did not even a year ago. The prospects are good for real transformation and quantum improvements in the higher education system as a whole.

\section{A Policy Shift in Botswana's Higher Education Landscape ISAAC N. OBASI}

Isaac N. Obasi is a senior lecturer in the Department of Political and Administrative Studies at the University of Botswana and secretary of the Tertiary Education Research Seminar. Address: Private Bag 0022, Gaborone, Botswana. He is also a regular columnist on higher education for the Daily Champion newspaper, Lagos, Nigeria. E-mail: zikobasi@yahoo.com and obasiin@mopipi.ub.bw.

A country with about I.7 million people, Botswana is generally described by development scholars as an exceptional African success story. Politically it has been a model of democracy on a continent where military dictatorship reigned for too long. It is also an economic miracle, having transformed itself from one of the poorest countries in the world at its independence in 1966 to its present status of a middle-income country. Presently, the country's tertiary education sector consists of one university and a number of other postsecondary institutions. A key feature of its higher education landscape is public ownership and control. However, as elsewhere, the forces of globalization and internal demands for expansion of access are exerting tremendous pressures for change. Consequently, in line with global trends, a new tertiary education policy is being proposed.

\section{Pressures on the Higher Education Landscape}

As the major actor, the government sponsors almost all tertiary education students both at home and abroad through the provision of student loans. Since I990, the government has been spending on average I percent of GDP on tertiary education, which is a reasonably high level compared to other African countries. However, enrollment figures at all tertiary institutions remain below the level of demand for access, with only I2 percent of the I8-24 age cohort presently at the range of institutions (awarding certificates, diplomas, or degrees) - as low as 6.9 percent of the higher education subsector.

The existing order has increasingly come under pressure for change. Proponents cite the inability of the existing university to expand access, which has already led to the idea of a second university. Designated as an international university of science and technology, the new university has been planned to introduce a new market orientation into the higher education landscape. Proponents also cite the overdependence of the university on government funding as both precarious and unsustainable. The decreasing support in the last two years is a danger signal. In the 2005/06 fiscal year, government funding provided about 66 percent of the university's budget.

\section{The Direction of the Emerging Policy}

In 2004, the Tertiary Education Council (TEC) established a Working Group on the Tertiary Education Policy for Botswana. The TEC wants the government to adopt a tertiary education policy that will be "cognizant of global trends and pressures that are impacting on tertiary education in Botswana" and "responsive to specific societal challenges and needs."

For example, some years ago, the University of Botswana implemented a restructuring policy in line with global trends of managerial-oriented leadership, privatization, the outsourcing of such services

Although the TEC proposes wider changes in line with globalization, it also provides an affirmation of some policies and practices that are already in place. For example, some years ago, the University of Botswana implemented a restructuring policy in line with global trends of managerial-oriented leadership, privatization, the outsourcing of such services, and the commercialization of some services. At the level of the state, the government has already adopted some neoliberal policies such as privatization, public-private partnership, and outsourcing of selected services.

In the education sector, the government has cautiously introduced a partial cost-sharing policy at the secondary school level as a testing ground for the future. Furthermore, ownership of tertiary education institutions has been liberalized and the extent of private providers is growing. It is estimated that in 2004, over Ioo private providers registered with the Ministry of Education, mainly for the running of nondegree technical and vocational programs. However, there are other foreign private providers running professional and master's degree programs. For example, the Limkokwing University in Malaysia has been offered registration by the TEC to run both diploma and degree programs. So far only a few private higher education providers have been registered and accredited by the TEC. 